\title{
Long time not seen: Expanding the records of Loxosceles amazonica (Araneae: Sicariidae) in the Amazonas state, Brazil
}

\author{
Marlus Q. ALMEIDA ${ }^{1 *}$, Lidianne SALVATIERRA ${ }^{2}$, Thiago G. CARVALHO ${ }^{1}$, Francisco J. PRESTES 3 , \\ Antonio D. BRESCOVIT ${ }^{4}$, Thierry R. GASNIER ${ }^{1}$ \\ 1 Universidade Federal do Amazonas, Departamento de Biologia, Laboratório de Ecologia Terrestre, CEP 69067-000, Av. Gal. Rodrigo Otávio Jordão Ramos 3000, Manaus, AM, \\ Brazil \\ 2 Instituto Nacional de Pesquisas da Amazônia - INPA, Coordenação de Biodiversidade - COBIO, Laboratório de Ecologia e Sistemática de Invertebrados do Solo, CEP 690160 - \\ 001, Av. André Araújo, Manaus, AM, Brazil \\ ${ }^{3}$ Escola Superior Batista do Amazonas, CEP 69057-510, Adrianópolis, Manaus, AM, Brazil \\ ${ }^{4}$ Instituto Butantan, Laboratório especial de Coleções Zoológicas, CEP 05503-900, Av. Vital Brasil, São Paulo, SP, Brazil \\ * Corresponding author: marlusqazoo@gmail.com
}

\section{ABSTRACT}

Spiders of the genus Loxosceles, commonly known as brown recluse spiders, can cause serious accidents in humans. Their venom has a powerful proteolytic and hemolytic action. Each year these spiders are the cause of a great number of araneism in Brazil. This work presents new records of Loxosceles amazonica for the municipal districts of Manaus and Iranduba, Amazonas, Brazil. KEYWORDS: Brown recluse spiders, venomous spider, loxoscelism, distribution

\section{Muito tempo sem ver: Expansão dos registros de Loxosceles amazonica (Araneae: Sicariidae) para o estado do Amazonas, Brasil}

\section{RESUMO}

As aranhas do gênero Loxosceles, conhecidas como aranhas marrons, podem causar sérios acidentes em humanos. O veneno destas aranhas possui potente ação proteolítica e hemolítica. A cada ano estas aranhas são responsáveis pelo maior número de araneísmos no Brasil. Este trabalho apresenta novos registros de Loxosceles amazonica para o estado do Amazonas, Brasil.

PALAVRAS-CHAVE: Aranha marrom, aranha peçonhenta, loxoscelismo, distribuição 
The brown recluse spider genus Loxosceles Heineken \& Lowe, 1832 is currently composed of 114 species (World Spider Catalog 2017). These spiders are predominantly found in the temperate and tropical regions of the Americas, Africa, and Europe (Duncan et al. 2010; Ramos et al. 2015; World Spider Catalog 2017). Spiders of the genus Loxosceles are not aggressive and accidents are usually triggered when spiders are pressed against the body, on clothing or in bedclothes during sleep (Gertsch 1967; Silva et al. 2004; Chapzaki et al. 2012).

Their venom has both proteolytic and hemolytic activity and can cause accidents with serious complications, which can even lead to death (Ramos et al. 2015). Twelve species of Loxosceles occur in Brazil: L. adelaida (Gertsch 1967), L. amazonica (Gertsch 1967), L. anomala (Mello-Leitão 1917), L. chapadensis (Bertani, Fukushima and Nagahama 2010), L. gaucho (Gertsch 1967), L. hirsute (Mello-Leitão 1931), L. immodesta (Mello-Leitão 1917), L. intermedia (Mello-Leitáo 1934), L. Laeta (Nicolet 1849), L. niedeguidonae (Gonçalvesde-Andrade et al. 2012), L. puortoi (Martins, Knysak and Bertani 2002) and L. similis (Moenkhaus 1898) (World Spider Catalog 2017). L. amazonica is currently reported for ten states in the Brazilian territory: Amazonas, Pará, Tocantins, Bahia, Ceará, Maranhão, Paraíba, Pernambuco, Piauí, and Mato Grosso, (Silveira 2015).

In Brazil, an average of 5000 cases of loxoscelism (envenomation by brown recluse spiders) are reported annually, with a high incidence for the South and Southeast region of the country. For the Amazonas state, the reported number of loxoscelisms from 2007 to 2015 is 183 (Ministry of Health 2016), which in itself indicates the presence of Loxosceles in the state. However, the only official record of L. amazonica in the Amazonas state was reported near the municipality of São Paulo de Olivença, in the west of the state, near the border with Colombia, and about $995 \mathrm{~km}$ from Manaus (Gertsch 1967).

No vouchers of $L$. amazonica exist in the largest invertebrate collections in Amazonas state, the invertebrate collections at Instituto Nacional de Pesquisas da Amazônia (INPA), and Universidade Federal do Amazonas (UFAM), and the arachnological collection of Fundação de Medicina Tropical Doutor Heitor Vieira Dourado (FMT-HVD), where most of the spider bite victims from the region of Manaus are treated. This paper expands the presence of L. amazonica for the municipal districts of Manaus and Iranduba, Amazonas, Brazil.

In 2016, 10 specimens (two males and eight females) were captured in Parque Amazonense, in Manaus (3.6'43.68"S, $\left.60^{\circ} 1{ }^{\prime} 5.77^{\prime \prime} \mathrm{W}\right)$. The specimens were collected manually inside of holes in the wall and under loose bark of trunks of a mango tree (Mangifera indica Linnaeus) and of a jackfruit tree (Artocarpus heterophyllus Lamarck). Another eight specimens (four males and four females) were found in the rural area of Vila de Paricatuba ( $\left.3^{\circ} 4^{\prime} 58.11^{\prime \prime} \mathrm{S}, 60^{\circ} 14^{\prime} 5.83^{\prime \prime} \mathrm{W}\right)$, in Iranduba municipality (Figure 1) and were collected inside of wall holes on the Paricatuba Ruins. Eggsacs and juveniles

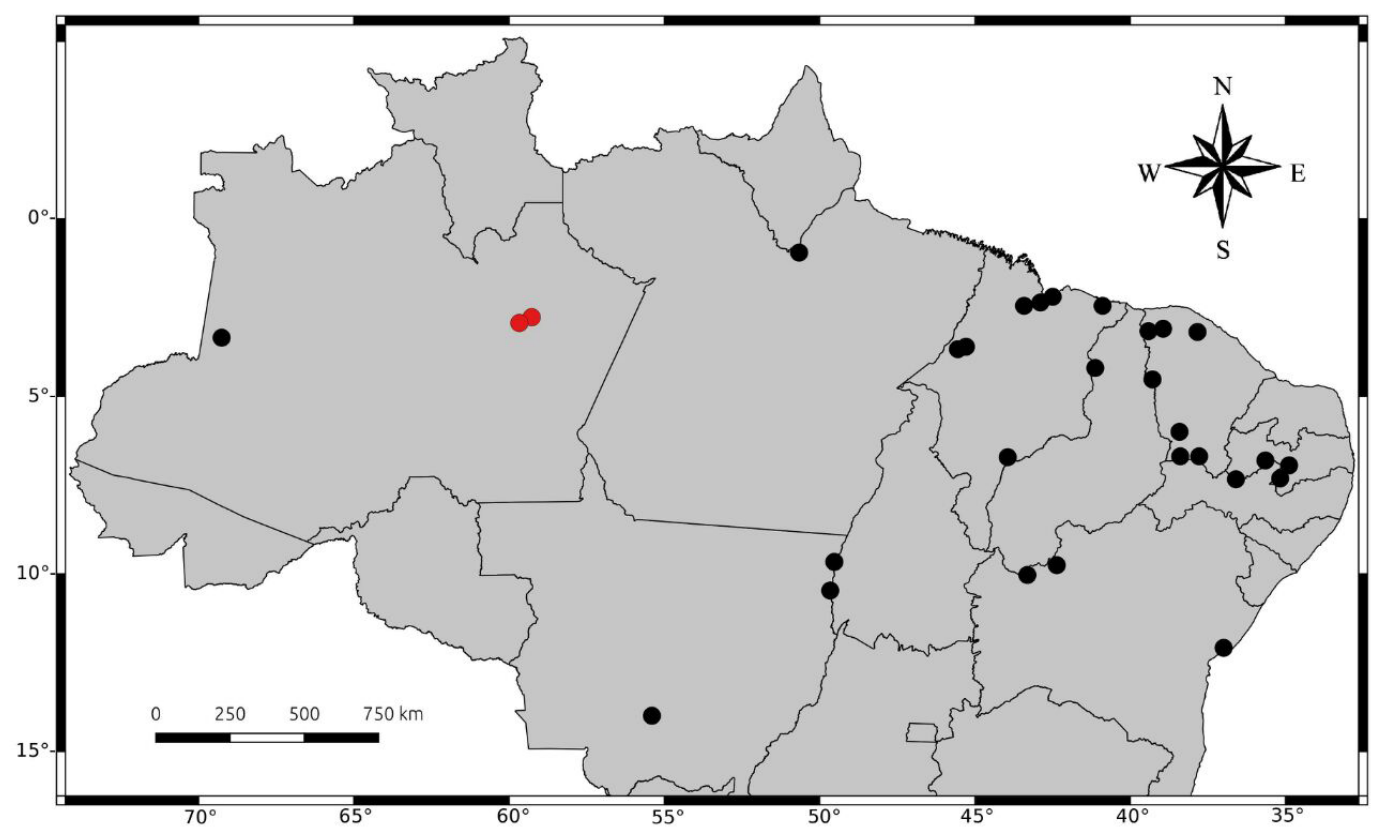

Figure 1. Known distribution of Loxoces/es amazonica in Brazil in the states of Amazonas, Pará, Tocantins, Bahia, Ceará, Maranhão, Paraíba, Pernambuco, Piauí and Mato Grosso (black circles). The red circles indicate the two new records in the state of Amazonas reported in here (municipalities of Manaus and Iranduba). This figure is in color in the electronic version. 
were also observed on nearby trees and walls. All material was collected at nighttime.

Specimen identification was made using Gertsch (1967). Loxosceles amazonica can be easily identified by males having the palpal tarsus considerably shorter than the tibia (Figure $2 \mathrm{~A}$ ), and the females having spermathecae with a group of small, globular lobes at the apex (Figure 2B) (Gertsch 1967).

Spiders were photographed alive, and then preserved in $99 \%$ ethanol. Ten specimens were deposited in the Invertebrate Zoology Collection at INPA, and eight specimens in the Zoological Collection Paulo Bührnheim at UFAM. The genital structures were examined under a Leica M80 stereoscope. The fixed specimens (Figure 2) were photographed with a Canon EOS 60D adapted on the base of an Olympus SZ200 stereoscope with Canon MPe 65mm $\mathrm{f} / 2.8$ lens. An EF $100 \mathrm{~mm} \mathrm{f} / 2.8 \mathrm{~L}$ macro IS USM lens was used for shooting specimens alive. The images were edited in Adobe Photoshop CS4 Extended (version 11.0.2). The distribution map (Figure 1) was created using Arcgis (version 10.4.1).

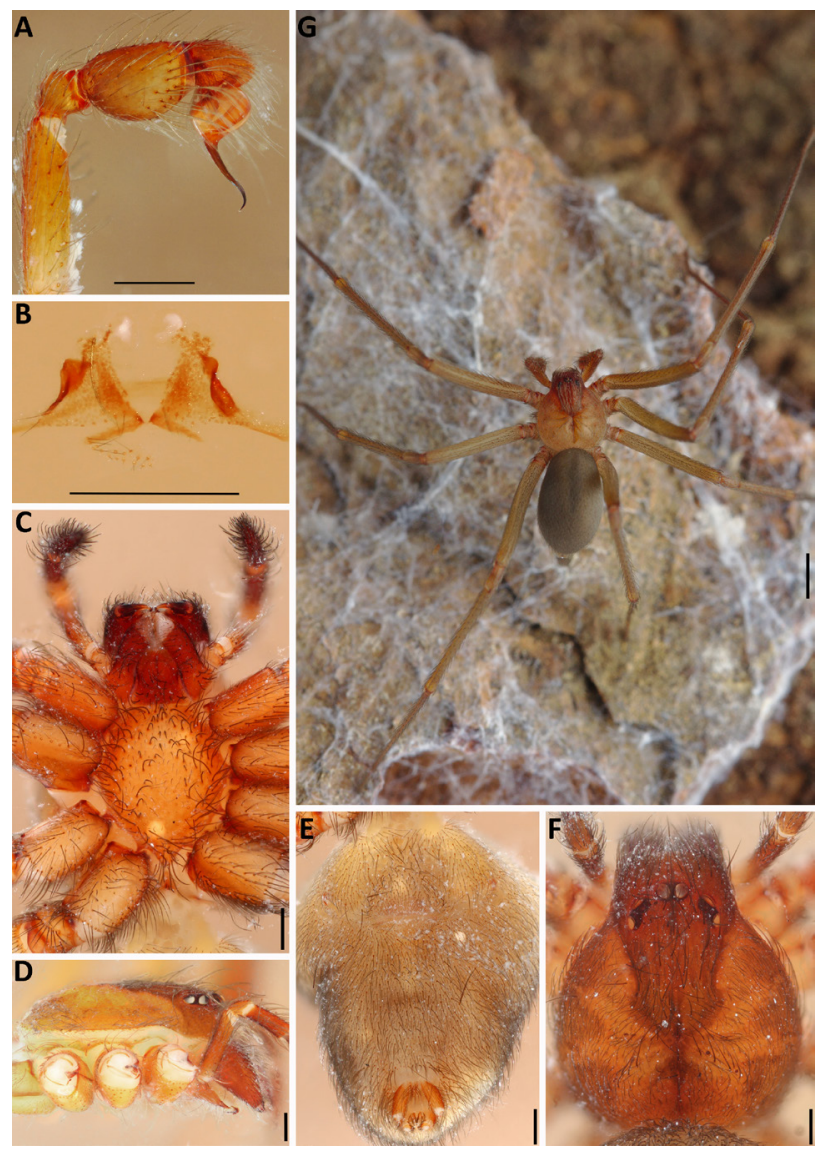

Figure 2. Loxosceles amazonica. A (male), palp; B (female), epigynum; C (female), sternum; D (female), carapace, lateral view; E (female), abdomen, ventral view; $F$ (female), carapace, dorsal view; $G$ (male), live specimen. Scale bars: A-F, $0.5 \mathrm{~mm} ; \mathrm{G}, 2 \mathrm{~mm}$. This figure is in color in the electronic version.
The report gap of almost 49 years between the first record of L. amazonica for the state of Amazonas (Gertsch 1967) and our report indicates that microhabitats are being neglected by zoologists and different choices of sampling methods should be used to access a broad guild structure and species diversity. The lack of Loxosceles in spider's inventories (e.g., Höfer and Brescovit 2001; Bonaldo et al. 2009) suggests that these animals may be highly synanthropic in this region, and were possibly introduced from natural population areas with rocks, inside or outside the Amazon region.

The spider collection at Fundação de Medicina Tropical, a reference hospital for tropical diseases, provides the standards for the correct identification of spiders brought in by victims of spider bites. Therefore the absence of $L$. amazonica vouchers in this collection is of wider concern, since they are necessary for the correct diagnosis of loxoscelism, which may require specific medical treatment.

Loxoscelim is a public health problem in south and southeastern Brazil, but its prevalence is still unknown in the Amazon region. It would seem important to increase the collection effort for this genus in synanthropic areas, as well as studies concerning the natural history and ecological studies of the species, in order to better understand the mode and intensity of interaction of these spiders with the human population in the Amazon region.

\section{ACKNOWLEDGMENTS}

We thank Renata Moroni for helping with the first version of the distribution map, and we would also like to thank two anonymous reviewers for constructive comments that greatly improved the manuscript.

\section{REFERENCES}

Bertani, R.; Fukushima, C.S.; Nagahama, R.H. 2010. Loxosceles chapadensis (Araneae: Sicariidae): a new recluse spider species of the gaucho group from Brazil. Journal of Arachnology, 38: 364-367.

Bonaldo, A.B.; Brescovit, A.D.; Höfer, H.; Gasnier, T.R.; Lise, A.A. 2009. A Araneofauna (Arachnida, Araneae) da Reserva Florestal Ducke, Manaus, Amazonas, Brasil. In: A fauna de Artrópodes da Reserva Florestal Ducke, Editora INPA, Manaus, p. 201-222.

Chatzaki, M.; Horta C.; Almeida, M. 2012. Cutaneous loxoscelism caused by Loxosceles similis venom and neutralization capacity of its specific antivenom. Toxicon, 60: 21-30.

Duncan, R.P.; Rynerson, M.R.; Ribera, C.; Binford, G.J. 2010. Diversity of Loxosceles spiders in Nothwestern Africa and molecular support for cryptic species in the Loxosceles rufescens lineage. Molecular Phylogenetics and Evolution, 55: 224-248.

Gertsch, W.J. 1967. The spider genus Loxosceles in South America (Araneae, Scytodidae). Bulletin of the American Museum of Natural History, 136: 117-174. 
Höfer, H.; Brescovit, A.D. 2001. Species and guild structure of a Neotropical spider assemblage (Araneae) from Reserva Ducke, Amazonas, Brazil. Andrias, 15: 99-119.

Gonçalves-de-Andrade, R. M.; Bertani, R.; Nagahama, R.H.; Barbosa, M.F.R. 2012. Loxosceles niedeguidonae (Araneae, Sicariidae) a new species of brown spider from Brazilian semiarid region. ZooKeys, 175: 27-36.

Martins, R.; Knysak, I.; Bertani, R. 2002. A new species of Loxosceles of the laeta group from Brazil (Araneae: Sicariidae). Zootaxa, 94: 1-6.

Mello-Leitâo, C.F.de. 1917. Notas arachnologicas. 5, Especies novas ou pouco conhecidas do Brasil. Brotéria (Ser. Zool.), 15: 74-102.

Mello-Leitão, C.F.de. 1931. Arachnidos do Rio Grande do Sul. Boletin Biologico Rio de Janeiro, 17: 10-14.

Ministério da Saúde. 2016. DATASUS, Tecnologia da Informação a Serviço do SUS. Acidentes por animais peçonhentos Notificações Registradas no Sistema de Informação de Agravos de Notificação - Amazonas. (http://tabnet.datasus.gov.br/cgi/ deftohtm.exe?sinannet/cnv/animaisAM.def ). Accessed on 05/09/2016.
Moenkhaus, W.J. 1898. Contribuiçao para o conhecimento das aranhas de Sáo Paulo. Revista do Museu Paulista, 3: 77-112 .

Nicolet, A.C. 1849. Aracnidos. In: Gay, C. (ed.) Historia física y política de Chile. Zoología, 3: 319-543.

The world spider catalog, version 18.0 (2017). American Museum of Natural History (http://research.amnh.org/entomology/spiders/ catalog/index.html). Accessed on 24/02/2017.

Ramos, R.F.M.; Girelli, L.P.; Toledo, D.W.; Ragnini, J.M.; Calcagnotto, F.N.; Silva, J.B. 2015. Acidente loxoscélico. Porto Alegre, Revista da AMRIGS, 59: 134-139.

Silva P.; Silveira R.; Appel M. 2004. Brown spiders and loxoscelism. Toxicon, 44: 693-709.

Silveira, A.L. 2015. New geographic records of the brown spider Loxosceles amazonica Gertsch 1967 (Araneae, Sicariidae) in Northeastern Brazil and its medical importance. Revista Médica de Minas Gerais, 25: 37-45.

Received: 09/09/2016

Accepted: 01/03/2017 